Jadwiga Wronicz

Instytut Języka Polskiego PAN, Kraków

jadwigaw@ijp-pan.krakow.pl

\title{
MOWA ŚLĄZAKÓW - GWARA, DIALEKT CZY JĘZYK REGIONALNY (W ZWIĄZKU Z PRÓBĄ ZMIANY STATUSU PRAWNEGO)
}

Słowa klucze: Śląsk, gwara, dialekt, język regionalny, status prawny

Keywords: Silesia, subdialect, dialect, regional language, legal status

W dialektologii polskiej używa się terminów dialekt na oznaczenie mowy rdzennych mieszkańców wsi większego obszaru i gwara na oznaczenie mowy jednej względnie kilku wsi, jednak w wielu pracach terminy te używane są zamiennie (EJP: 66, 122). $\mathrm{W}$ artykule przez termin gwara rozumiem mowę konkretnego, mniejszego obszaru, przy czym nie musi to być obszar wiejski, natomiast dialekt to zespół cech gwarowych, wspólny dla sąsiadujących ze sobą gwar, charakterystyczny dla większego obszaru i pozwalający go odróżnić od sąsiednich obszarów.

W ostatnich latach obserwujemy działania zmierzające do zmiany statusu mowy mieszkańców Górnego Śląska i uznania jej za odrębny od polszczyzny język regionalny. Po raz pierwszy projekt takiej zmiany został przedłożony w Sejmie w roku 2007, nie został jednak wtedy rozpatrzony. Projekt z 29 października 2010 r. został zaopiniowany w maju 2011 r. przez Radę Języka Polskiego. Rada wypowiedziała się przeciwko uznaniu mowy Ślązaków za osobny język. 30 marca 2012 r. został złożony w Sejmie Rzeczypospolitej Polskiej trzeci projekt. Dotyczy on - podobnie jak poprzednie - nowelizacji ustawy, uchwalonej 6 stycznia 2005 r., o mniejszościach narodowych i etnicznych oraz o języku regionalnym, która, jak pamiętamy, nadała kaszubszczyźnie 
status języka regionalnego ${ }^{1}$. Projekt z roku 2012 podpisany przez Marka Plurę oraz 63 innych posłów przewiduje, że status języka regionalnego otrzyma także język śląski. Do pisma dołączono Uzasadnienie (s. 7-13)², do którego chcę się ustosunkować.

Autorzy powołują się na Europejską kartę języków regionalnych lub mniejszościowych. Karta ta zobowiązuje państwa do zapewnienia użytkownikom możliwości pielęgnowania i upowszechniania własnego języka oraz posługiwania się nim w szkolnictwie, administracji, sądownictwie, umowach handlowych itp.

Według tej karty (część 1., art.1. Definicje)

[...] języki regionalne lub mniejszościowe oznaczają języki, które są: 1. tradycyjnie używane na terytorium danego państwa przez jego obywateli stanowiących grupę liczebnie mniejszą od reszty ludności tego państwa oraz 2. różnią się od oficjalnego języka tego państwa; nie obejmuje to ani dialektów języka oficjalnego państwa, ani języka migrantów³.

Autorzy projektu twierdzą, że „pojęcie ‘język regionalny’ nie ma znaczenia - nie funkcjonuje w obszarze pojęciowym lingwistyki” (Uzasadnienie: 7).

Otóż pojęcie to funkcjonuje. Wprowadził je po raz pierwszy Zenon Klemensiewicz w klasyfikacji odmian polszczyzny. Jako jednostkę nadrzędną wprowadził język narodowy, który - w ujęciu tego badacza - obejmuje język ogólny używany w sytuacjach oficjalnych, będący przedmiotem nauki szkolnej, i język regionalny - zróżnicowany terytorialnie język mieszkańców wsi, czyli po prostu wszystkie gwary łącznie (Klemensiewicz 1954: 374). Takie rozumienie pojęcia język regionalny nie przyjęło się w polskim językoznawstwie, upowszechnił się natomiast termin regionalizm, oznaczający cechę językową ograniczoną do pewnego terenu, występującą także w języku ludzi wykształconych, czym różni się on od dialektyzmu, czyli cechy gwarowej, która w języku ludzi wykształconych się nie pojawia (EJP: 318) (chyba że jest elementem stylizacji w dziele literackim). W literaturze pojawia się termin polszczyzna regionalna. Przyjmując synonimiczność pojęć język polski i polszczyzna, można by uważać, że język regionalny jest to odmiana języka ogólnopolskiego zawierająca regionalizmy. Jednak Europejska karta języków regionalnych lub mniejszościowych nie uwzględnia takiego znaczenia.

1 Odrębność kaszubszczyzny w stosunku do wszystkich pozostałych dialektów była od początku zauważana w polskiej dialektologii, stała się też podstawą uznania kaszubszczyzny za język regionalny. Trzeba też dodać, że ta decyzja Sejmu z roku 2005 nie jest wiążąca dla badań dialektologicznych i dlatego niektóre z prac syntetycznych dotyczących dialektów polskich nie wyłączają Kaszub z pola swoich badań. Proces standaryzacji języka kaszubskiego nie jest jeszcze zakończony i nie u wszystkich Kaszubów zyskuje akceptację.

2 Pod tekstem Uzasadnienia nie ma podpisu, wobec czego traktuję sygnatariuszy projektu nowelizacji ustawy jako autorów.

3 http://www.msw.gov.pl/download/1/9107/Europejskak_karta_jezykow_regionalnych_lub_mniejszosciowych.pdf 
Ponieważ w karcie wyraźnie zaznaczono, że nie dotyczy ona dialektów, w uzasadnieniu wniosku autorzy starają się wykazać, że mowa Ślązaków nie jest dialektem, tylko odrębnym językiem. Powołują się na opinie „wielu współczesnych lingwistów polskich" (nie podając ich nazwisk ani tytułów prac), którzy jakoby twierdzą, iż

[...] język regionalny wykracza poza pojęcie dialektu wtedy, gdy w toku swego rozwoju osiąga następujące cechy: swoistość sfery językowej; posiadanie osobnego piśmiennictwa; świadome rozwijanie języka, literatury, własnej kultury; osobliwe obyczaje; spontaniczne i świadome nastawienie na odrębność (Uzasadnienie: 7).

O ile mi wiadomo, w literaturze naukowej z zakresu dialektologii nie spotyka się tak sformułowanego wyznacznika. Co do świadomego rozwijania własnej kultury i poczucia własnej odrębności - są to cechy obligatoryjne każdej wspólnoty; nie wynika z nich, że dana wspólnota traktuje je jako opozycyjne w stosunku do wspólnoty językowej. Trzeba jednak przyznać, że w przemysłowej części Śląska poczucie odrębności rodowitych Ślązaków - w stosunku do mieszkańców innych regionów i przybyszów - jest bardzo mocne, co wiąże się ze specyficzną historią tego regionu (Skudrzykowa i in.: 2001; Siuciak 2011).

Autorzy, powołując się na opinię upowszechnianą przez Tomasza Kamusellę, przyjmują, że

[...] o tym, czy coś jest dialektem jakiegoś języka, czy też odrębnym językiem decydują kryteria pozajęzykowe: wola użytkowników danej mowy oraz decyzje polityczne (Uzasadnienie: 8).

Decyzje polityczne mogą dotyczyć języka państwowego, nie dotyczą natomiast języków narodowych i wchodzących w ich skład dialektów. Ważnym argumentem jest tu fakt, że granice między dialektami polskimi a dialektami sąsiednich języków zostały wyznaczone na początku XX w. w oparciu o cechy wewnątrzjęzykowe, na podstawie badań mowy ludności autochtonicznej, a nie w wyniku decyzji politycznych władz Rosji, Prus i Austrii, które to państwa obejmowały terytoria dzisiejszej Polski i innych krajów słowiańskich.

Kształtowanie się języków narodowych i różnicowanie się dialektów są procesami długotrwałymi. W języku spotykamy zjawiska będące skutkiem przekształceń, które dokonały się przed wiekami, i dlatego ich klasyfikacja opiera się na badaniach historyczno-porównawczych. Twierdzenie, że mowa Ślązaków nie jest dialektem polskim, jest równie bezpodstawne, jak twierdzenie, że język polski nie jest językiem słowiańskim.

Bezpodstawne jest także używanie przez autorów Uzasadnienia wyrażenia etnolekt śląski (Uzasadnienie: 7 i n.). Trzeba przypomnieć, że termin etnolekt, obejmujący zarówno języki, jak i dialekty, został wprowadzony przez Alfreda Majewicza ze względu na istnienie języków - jak pisze autor - „dotychczas bardzo słabo zbadanych lub zupełnie nieznanych” (Majewicz 1989: 10), nie ma więc powodu, by stosować go do języków europejskich. 
Niektóre sądy zawarte w omawianym Uzasadnieniu nie budzą wątpliwości. Trzeba się zgodzić z poglądem, że „posługiwanie się regionalizmami jest słabo tolerowane w życiu publicznym” i dlatego ich użytkownicy „są skłonni podnosić prestiż swojego dialektu, określając go jako odrębny język bądź jako język regionalny" (Uzasadnienie: 8). Autorzy co prawda mylnie utożsamili użytkowników regionalizmów z użytkownikami dialektu, ale dotknęli istotnego problemu: dialekty mają w kulturze polskiej bardzo niską pozycję, dlatego powszechne jest przekonanie, że gwary trzeba się wstydzić (Kucała 1960; Skudrzyk 2004; Skudrzyk, Urban 2010: 25). Wiąże się to z wielowiekową dominacją kultury szlacheckiej nad kulturą chłopską, przekształconą następnie w kulturę inteligencką (więcej zob.: Wronicz 2010). Zjawisko unikania gwary było powszechne już na początku XX w. ${ }^{4} \mathrm{i}$ ten stan nie uległ zmianie ani po odzyskaniu niepodległości, ani po II wojnie światowej. Nośnikami kultury wysokiej są mieszkańcy miast posługujący się językiem ogólnym, natomiast ludzie mówiący gwarą są kojarzeni z wiejskością i prymitywizmem. Dlatego niektórzy działacze regionalni próbują podnieść prestiż gwary i dążą do jej traktowania jako autonomicznego języka. Ukształtowało się kilka ośrodków regionalnych o ambicjach językowych: śląski, podhalański, podlaski i kurpiowski. Antoni Furdal łączy to zjawisko z ogólnymi tendencjami do dezintegracji we współczesnej Europie (Furdal 2002), natomiast Bogusław Wyderka określa te działania jako „emancypację dialektów”. Jego zdaniem w wypadku Śląska można mówić o pierwszej fazie wyłaniania się nowego języka (Wyderka 2012).

W moim przekonaniu powszechnie panujący negatywny stosunek do wiejskości i kojarzonej z nią gwary jest jednym z głównych powodów obserwowanego zjawiska. Wielu użytkowników gwary doświadczyło, np. w szkole, piętnowania czy wyśmiewania przez kolegów, a nawet nauczycieli. Jednocześnie ta odmiana języka - jako język pierwszy - była językiem najbliższym sercu i dlatego jej wyśmiewanie odczuwano jako szczególnie bolesne. Nie można się więc dziwić, że zwolennicy odrębności językowych odwołują się do poczucia krzywdy i eksponują opozycję: my - oni. Wprawdzie mieszkańcy przemysłowej części Śląska posługujący się gwarą nie są wieśniakami, ale niskie wartościowanie gwary występuje także tutaj. Przejawia się ono w unikaniu cech o wyraźnie gwarowej proweniencji i zmniejszaniu się liczby użytkowników gwary. Zdaniem Jolanty Tambor czynniki te „stwarzają groźbę nieodległego zniknięcia gwary przemysłowego Górnego Śląska z rejestru odmian polszczyzny" (Tambor 2008: 292).

Mimo wskazanych psychologicznych racji Uzasadnienie zawiera jednak liczne dyskwalifikujące je błędy, nieścisłości, nieprawdziwe informacje. Przykładowo, autorzy Uzasadnienia, wnioskując o prawne uznanie języka śląskiego, powołują się na opracowania zagranicznych językoznawców, którzy ów status uznali, m.in. Reinholda Olescha (1958), oraz na opinię historyka Normana Daviesa, a także na amerykańską

4 Kazimierz Nitsch pisze: „Śląsk [...] jest to jedyna znana mi część Polski, gdzie nieliczna klasa wykształcona (nawet uczniowie polskiego gimnazjum w Cieszynie) nieraz świadomie posługuje się w mowie potocznej dialektem" (Nitsch 1909: 95). 
Encyklopedię Słowiańską, Międzynarodową Organizację Językową (International Organization for Standardization), Bibliotekę Kongresu Stanów Zjednoczonych, jak zaznaczają - „największą i najbardziej prestiżową instytucję tego typu na świecie” które jakoby oficjalnie wpisały język śląski do rejestru języków świata (Uzasadnienie: 9). Błędy i nieścisłości w tym punkcie Uzasadnienia szczegółowo omówiła Bożena Cząstka-Szymon (współautorka Małego słownika gwary Górnego Śląska, konsekwentnie krytykująca nierzetelność i upolitycznienie obecnej dyskusji na temat gwar śląskich: Cząstka-Szymon 2009a, 2009b, 2011, Cząstka-Szymon, Synowiec, w druku) ${ }^{5}$.

Dodam, że argumenty autorów Uzasadnienia polegające na powoływaniu się na ustalenia zewnętrzne mogłyby być przekonujące, gdyby chodziło o kulturę społeczności o takim stopniu rozwoju, że nie dysponuje ona własnym piśmiennictwem, a zatem nie może snuć refleksji naukowej nad używanym przez siebie językiem, jednak w tym wypadku takie uzasadnianie stanowiska musi budzić zdziwienie. Autorzy zignorowali dorobek polskiego językoznawstwa dotyczący Śląska.

Trzeba więc przypomnieć, że badania nad dialektem śląskim mają długą tradycję. Monografia dialektu śląskiego powstaje już na początku XX w. Jej autorem jest Kazimierz Nitsch (1909). Wcześniej jeszcze mamy pracę Lucjana Malinowskiego zawierającą opis mowy mieszkańców kilku wsi położonych na Śląsku Opolskim (Malinowski 1873) oraz rozprawę Jana Bystronia na temat południowo-zachodniej części Śląska Cieszyńskiego (Bystroń 1887). Następnie badania dotyczące Śląska podejmują w ośrodku uniwersyteckim wrocławsko-opolskim: Stanisław Rospond, Stanisław Bąk, Henryk Borek, Walenty Dobrzyński, Feliks Pluta, Jan Miodek, Bogusław Wyderka; w ośrodku uniwersyteckim krakowsko-katowickim początkowo Alfred Zaręba, potem: Alina Kowalska z zespołem (Urszula Burzywoda, Mirosława Siuciak), Władysław Lubaś, Bożena Cząstka-Szymon z Heleną Synowiec, Jolanta Tambor, Aldona Skudrzyk, Olga Wolińska, Krystyna Urban; Śląska Cieszyńskiego dotyczą prace Jana Basary, Daniela Kadłubca, Janiny Labochy, Roberta Mrózka, Zbigniewa Grenia, Ireny Bogocz, Beaty Kubok i in. Ze słowników trzeba wymienić rękopiśmienny Słownik dialektyczny Księstwa Cieszyńskiego Andrzeja Cinciały (1882), Mały słownik gwary Górnego Śląska pod redakcją Bożeny Cząstki-Szymon, Jerzego Ludwiga i Heleny Synowiec (2000), Słownik gwarowy Śląska Cieszyńskiego pod redakcją Jadwigi Wronicz (1995), a przede wszystkim Słownik gwar śląskich pod redakcją Bogusława Wyderki (2000-2012). Wymienione prace pozwalają na dokładniejszą charakterystykę gramatyczną i leksykalną dialektu śląskiego i poszczególnych gwar wchodzących w jego skład oraz pokazują jego historię i ścisły związek z innymi dialektami polskimi. Także prace syntetyczne uwzględniają Śląsk jako jeden z głównych dialektów polskich. Wymieńmy przykładowo Słownik gwar polskich Jana Karłowicza (1900-1911), Dialekty języka polskiego (1915) i Wybór polskich tekstów gwarowych $(1929,1960)$ Kazimierza Nitscha, Mały atlas gwar polskich, t. I-II (1957-1959) pod redakcją Kazimierza Nitscha, t. III-XIII pod

5 Zob. Opinię... autorstwa B. Cząstki-Szymon, którą publikujemy po niniejszym artykule - Red. 
red. Mieczysława Karasia (1960-1970), Dialekty polskie Karola Dejny (1973), Słownik gwar polskich PAN (od roku 1977 - dotąd ukazało się osiem tomów w 25 zeszytach, z hasłami na litery A-G), oraz najnowszą monografię multimedialną Haliny Karaś pt. Gwary polskie (www.gwarypolskie.uw.edu.pl).

Prace te pozwalają na usytuowanie dialektu śląskiego w stosunku do innych dialektów oraz na jednoznaczne stwierdzenie jego przynależności do polszczyzny. Jak wiadomo, zasadniczym kryterium podziału obszaru Polski na dialekty były cechy fonetyczne: mazurzenie i udźwięcznienie międzywyrazowe. Co do pierwszego zjawiska - część północna Śląska, granicząca z niemazurzącą Wielkopolską - mazurzy, natomiast środkowa i południowa, granicząca z Małopolską - nie mazurzy. Wymowa udźwięczniająca jest wspólną cechą Wielkopolski, Śląska i Małopolski. Każdy z dialektów ma cechy typowe dla siebie, choć występują one także poza nim, ale na mniejszym obszarze lub w mniejszym zakresie. I tak cechami całego Śląska są grupa $r z i$

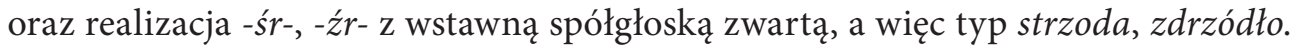
Pierwsza z nich występuje także w południowej Małopolsce, druga na Kaszubach. Cechą typowo śląską jest też realizacja $e$ pochylonego jako $y$ zarówno po spółgłoskach twardych, jak i miękkich, a więc syr, mlyko, wiym, umiym. Ten typ wymowy występuje także w Małopolsce i w Wielkopolsce, jednak nie na całym obszarze. Śląsk środkowy i północny charakteryzuje się obecnością dyftongów: suchoł trołwa, pomełgać, u nołs, niejsie, czym upodabnia się do sąsiadujących z nim gwar wielkopolskich. Samogłoska ę $\mathrm{z}$ wyjątkiem części południowej ma brzmienie $a$ nosowego lub w wygłosie $a$, co słychać w typowo śląskim widza ta dziołszka. Rozszerzona wymowa nosówki przedniej występuje także w gwarach Małopolski, Mazowsza i północnej Wielkopolski. Widać stąd, że dialekty nie stanowią terenów izolowanych językowo; granice między nimi wyznaczane są przez wiązki izofon. Podobnie jest z leksyką.

Podam kilka obserwacji poczynionych na podstawie Małego słownika gwar polskich (Wronicz 2009), w którym zebrano wyrazy charakterystyczne dla poszczególnych dialektów i całego obszaru gwarowego Polski. Spośród 11794 wyrazów gwarowych aż 3155, czyli niemal 27\%, jest poświadczonych na Śląsku. Na tę sumę składają się wyrazy charakterystyczne dla Śląska oraz wspólne dla Śląska i pozostałych dialektów ${ }^{6}$. Do pierwszej grupy wyrazów ${ }^{7}$ występujących według autorów Małego słownika gwar polskich wyłącznie lub niemal wyłącznie na Śląsku (Śl) należą:

rzeczowniki:

bajtel 'mały chłopiec': Te, bajtel, je dóma foter? Rogów ryb; bera 'bajka, opowieść zmyślona': Snochwio [zmyśla] rozmańte bery, klechce ludzióm, a potym sie tego wypiyro Czyżowice ryb; cera 'córka': Gdo mo cery na wydaju, musi chować moc gyńsi - aby było piyrzi na pierziny Rogów ryb; chachar 'człowiek zły, łotr': Taki był szykowny synek, jak

6 Zasady doboru haseł i lokalizacji zostały podane we Wstępie, s. 6-8.

7 Hasła mają postać literacką, np. familak, natomiast w cytatach uwzględniono wymowę gwarową, np. familok, co wyjaśniono we Wstępie, s. 8-10. 
był mały, a teraz sie zrobił taki chachar Puńców ciesz; dąga, dęga 'tęcza': Dónge na niebie robi Pómbóczek Karwina [Cieszyn Cz]; familak 'duży dom mieszkalny na Śląsku, zamieszkiwany przez większą liczbę rodzin robotniczych': Ón synek z gospodarstwa, a dziołchu se biere z familoków Rogów ryb; frela, frelka 'kobieta niezamężna': "Ón se wzión frela z miasta Jędrysek lubl; gruba 'kopalnia': Jeji chłop robi na grubie i szykowny pinióndz zarobi Rogów ryb; herbowizna 'spadek': 1000 reńskich jako herbowizny w kopce ziemniaków znaleźli po jej śmierci Mysłowice; karlus 'chłopak, kawaler': Na muzyce było moc karlusów ze Zowady Rogów ryb; knefel 'guzik': Piékne knefle mocie przy tymu mantlu Jankowice Rybnickie ryb; maszka 'kokarda': We włosach miała szumno maszka Rogów ryb; moczka 1. 'śląska potrawa wigilijna z moczonego piernika, owoców i bakalii': Ślepou ryba - mouczka - to idzie do tygo: śliwy, rouzynki, pastyrnouk Stara Jamka niem; Panbóczek, Pambóczek 'Pan Bóg’: Mój ty Pómbóczku, dej abychmy byli zdrowi Rogów ryb; paterek 'młody ksiądz, wikary': Spowiado farorz i paterek Kozakowice ciesz; pąć 'pielgrzymka': Mamulka nasza chodziyli na pónć do Czynstochowy Jankowice Rybnickie ryb; piska 'kreska': Kiery zaś zrobił te piske na ścianie? Puńców ciesz; przaciel 'krewny': Bydziesz pytany na weseli? Możnej byda, przecach je jeji przociel Rogów ryb; przyleżytość 'okazja, sposobność: Choby i była przileżytoś iś do miasta, to nie pójda, bo ni móm po co Rogów ryb; przywiarki 'zabobony, przesądy': Śl; pyrlik 'młot lub młotek': po zieleźnych klinach piźnij pyrlikym, a po drzewiannych palicóm Rogów ryb; pytlik 'woreczek': Dzieci przyniysły od starki gruszek $w$ pytliku Rogów ryb; slabikarz, ślabikarz 'elementarz': Ze ślabikorza my czytali Jankowice Rybnickie ryb; synek 'chłopiec': Starszych synków na muzyce było mało, a tak same młodzioki Rogów ryb; szłapa 'stopa człowieka lub łapa zwierzęcia': Mosz takie szłapy, ze ci żodyn trzewik nie pasuje Jędrysek lubl; sztwierć 1. 'jednostka objętości produktów sypkich (najczęściej ziarna), będąca czwartą częścią korca; także naczynie, zwykle drewniane, używane do odmierzania tej objętości’: Śl; 2. 'część sąsieka w stodole': Siano swalył na gumno, bo we sztwierci ni ma placu Rogów ryb; 3. 'czwarta część godziny; kwadrans': Wiela je godzin? Trzi sztwierci na jedna [godz. 12:45] Rogów ryb; 4. 'faza księżyca; kwadra': Wiotek - jak już je "ostatnio sztwierć, jak juz zaś je ku nowu Kozakowice ciesz; tacik pieszcz. 'ojciec': Jo je w tych samych latach, co twój tacik, my chodzili do kupy do szkoły Rogów ryb; wieprzki 'agrest': Wieprzków sie nażroł, a teraz go w brzuchu puczy Czyżowice ryb; żemła 'bułka': Kup pecynek chleba a sztyry żymły Jankowice Rybnickie ryb; żydlik 'naczynie do picia trunków, kufel': Stará kwárta, a nowy żidlik to jedno Jaworzynka ciesz;

\section{czasowniki:}

biglować 'prasować żelazkiem': Trza biglować uobrusy Koniaków ciesz; kludzić 'prowadzić': Uż zaś ['znowu'] wczora kludzili tego ożyroka ['pijaka'] Olza ryb; też: przykludzić, wykludzić, zakludzić, poskludzać; klupać 'stukać, pukać: Jak chcesz wlyjś dziołcha, to musisz fest klupać, bo jo już tak dobrze nie słysza Jankowice Rybnickie ryb; luftować 'wietrzyć': Pierziny luftować, jizbą luftować Zarzecze ciesz; naciepać 'narzucać, nawrzucać': Telaście naciepali na ta fura, przeca jedyn kón tego nie ucióngnie Rogów ryb; też ściepać, wyciepować; marasić 'brudzić': Nie maraś mi podłogi Harbutowice ciesz; też namarasić, zamarasić, zmarasić; ogibać (się) 'zginać, uginać (się)’: Nie uogibej tego biczyska, bo go złómiesz Kozakowice ciesz; paradzić się 'wynosić się nad innych, pysznić się’: Ty sie ale 
paradzisz teraz, jak-eś sie wydała, ani nie przidziesz uż dó nas Rogów ryb; piskać 'grać na fujarce': Ustrugoł se piszczołka z wiyrby i pisko jak gupi Rogów ryb; pobrusić 'naostrzyć': Kosa je zło, pobruś jóm osełkóm! Rogów ryb; pokidać (się) 'pobrudzić (się), polać (się) czymś': Pokidoł serwet bryjóm Harbutowice ciesz; pozdrzeć 'spojrzeć, popatrzeć': Pozdrym tam, czi go uż ni masz Jaworzynka ciesz; Śl; przać 'kochać, lubić, sprzyjać': "Ón bardzo przaje dziecióm Jędrysek lubl; przeblec 'przebrać ubranie, bieliznę pościelowąa': Łóżka mamy przeblecóne, niy? Kochłowice klucz; rzekać 'modlić się': Jaby go mamulka do kościoła nie wyganiali, to by nie szoł, ón yny z musu chodzi rzykać Rogów ryb; szydzić 'kłamać, oszukiwać': Uczciwy - nie szydzi, prouwda mówi Śl; wylękać się 'przestraszyć się’: Dej pozór, żeby sie dziecko nie wylynkało, bo go bydzie wrzód "obrożoł ['dostanie ataku epilepsji'] Rogów ryb; zbulić 'zburzyć, zniszczyć': Zbula tyn chlywek, bo mi szpeci plac Marklowice ryb; zmazać (się) 'ubrudzić (się)': Dziecka sie zaś bawióm w kałuży, dyć sie zmażóm Puńców ciesz;

\section{przymiotniki:}

reżny 'żytni’: Na klyj musi być reżno mónka. Móm pełno reżnego ościo za koszulóm i pcho mie to pierónym Rogów ryb; roztomiły 'drogi, kochany’: Roztomity syneczek, ón jedyn o staro matka dbo Rogów ryb; sagi 'nagi': "Oblykej sie, bo nie bydziesz sagi po chałupie łaziół Jankowice Rybnickie ryb; słuszny 'poważny, skupiony, zamyślony’: Cóżeś zaś je taki słószny? Kozakowice ciesz; snażny 'schludny, czysty’: To je snożny człowiek Zarzecze ciesz; spórny 'gniewliwy, często się sprzeczający': Taki spórne dziecko: siadło na ziym i kopie ze spóry nogami i żodyn mu nic nie powiy Rogów ryb; zachciały, zachciwny 'kapryśny': Niy bóńdź taki zachciały! Jędrysek lubl.

Takich wyrazów jest w omawianym słowniku 1464.

Pozostałe wyrazy, oznaczone w słowniku jako odnotowane na Śląsku (Śl), są wspólne dla Śląska i innych dialektów (Wp, Mp, Kasz, Maz), np.:

baba 1. 'kobieta, mężatka': ogólnogwarowe; 2. 'akuszerka': Śl, Mp; cedziłko, cedzitko 'szmatka lub przyrząd z sitkiem do cedzenia mleka po dojeniu': Śl, Maz, Kresy pn; dęga 'ślad na ciele po uderzeniu batem; pręga': Śl, Wp; dwierka 1. 'małe drzwi': Śl, Kasz; 2. 'małe drzwi do pieca kuchennego, też piekarskiego': Śl, Kasz; gibki 'o człowieku: zwinny, zręczny': Twoja matka staro, ale jeszcze gipko Jędrysek lubl; Śl, Mp; gichnąć 1. 'gwałtownie wylać': We śmiergus Francik całe wiadro wody gichnył na Maryka Rogów ryb; Śl, Wp; kapałka 'serwatka': Kiszka ['kwaśne mleko'] sie uż zesyrzyła, odlyj ś ni kapołka Rogów ryb; Śl, Wp; klin 1. 'miejsce na kolanach, podołek': Dziecko siedziało mi na klinie Jędrysek lubl, Śl, Wp pd, Kasz; kupczyk 'sprzedawca': Kupczyk sprzedaje w sklepie Puńców ciesz; Śl, Kasz; mamulka pieszcz 'matka': Moja mamulka je nejlepszo Puńców ciesz; Śl, Kasz; mantel 'płaszcz': Już ubiéróm mantel a ida s wami Jankowice Rybnickie ryb; Śl, Mp, Maz, Wp, Kasz; maśniczka 'naczynie z klepek służące do wyrobu masła': Śl, Mp, Maz pd-wsch; miano 'imię’: Maryja to je piekne miano, zocne Koniaków ciesz; Śl, Mp pd, Kasz pn; mręgaty ‘pręgowaty, pstry’ Śl, Mp pn-zach; nakurzyć 'o śniegu: napadać: Przez noc nakurziło śniegu Łomna Górna [Cieszyn Cz]; Śl, Mp, Pom pd; nasuć 'nasypać': Śl, Mp, Wp; odewrzeć (się) 'otworzyć, odemknąć': Śl, Mp; opucować 
1. 'oczyścić’: Śl, Mp pd; osiewać 'przesiewać przez sito’: Śl, Maz, Wp; reż ‘żyto’: Downi my nigdy rży nie wożyli, yno mierzyli na miarki Rogów ryb; Śl, Maz pn; rzecz 'język, mowa, rozmowa, mówienie’: Ta głupio rzecz sie sypie z niego jako z kozy bobki Kozakowice ciesz; Śl pd, Mp pd-zach; seblec (się) 'zdjąć ubranie, rozebrać się': Do koszule go seblykli, w koszuli stoł na mrozie Karwina [Cieszyn Cz]; Ty niestydniku, jako sie tak umisz seblyc przed ludziami Rogów ryb; Śl, Wp zach, Kasz pn; taciczek pieszcz. 'ojciec': Taciczku, zezwólcie iś Maryce na muzyka! Rogów ryb; Śl, Mp pd-zach; tylki, telki 'tak duży, taki': Śl, Maz, Wp, Kasz; wieja 'wichura, zawierucha, zadymka': Jak tu iś bez tako wija Jędrysek lubl; Śl, Wp, Kasz.

Takich wyrazów jest 1691. Wyrazy śląskie wspólne z innymi dialektami stanowią 53,6\%, a wyrazy odrębne $46,4 \%$ wszystkich dialektyzmów śląskich zanotowanych w $\mathrm{Ma}$ łym słowniku gwar polskich. Dla porównania w dialekcie małopolskim proporcje te układają się nieco inaczej: wyrazów wspólnych z innymi dialektami jest 2 127, a tylko małopolskich 2 738, czyli 44 do 56\%. Można zatem stwierdzić, że ani pod względem gramatycznym, ani ze względu na słownictwo Śląsk nie stanowi jednostki odrębnej językowo od innych regionów Polski.

Autorzy Uzasadnienia powołują się na fakt, że w Narodowym Spisie Powszechnym z roku 2002 ponad 56 tysięcy osób zadeklarowało śląski jako język używany na co dzień. Można na tej podstawie wnioskować, że jest to dialekt żywy, funkcjonujący do dzisiaj, a nie, że jego użytkownicy uważają go za osobny język. Posługiwanie się dialektem w kontaktach nieoficjalnych przez mieszkańców danego regionu jest zjawiskiem powszechnie występującym w wielu krajach Europy i nie jest podstawą do ubiegania się o status języka regionalnego.

Posiadanie osobnego piśmiennictwa także nie jest wystarczającym argumentem. Jeżeli uznajemy gwarę za odmianę języka polskiego, to tekstu nią napisanego nie możemy sytuować poza literaturą polską. Pogląd, że tylko język ogólnopolski może być tworzywem dzieła literackiego, należy uznać za przestarzały. W ujęciu Antoniego Furdala każda z wyróżnionych przez niego warstw języka, czyli język ludowy, język miejski i język literacki, może być tworzywem języka artystycznego (Furdal 200o: 170-175). Na Skalnym Podhalu Kazimierza Przerwy-Tetmajera, Słowo o ślebodzie Józefa Tischnera, twórczość Hanki Nowobielskiej, Henryka Jasiczka, Heleny Kupcowej, Juliusza Wątroby, Józefa Musioła czy Zbigniewa Kadłubka i wielu innych pisarzy piszących gwarą należą do literatury polskiej. Osobnym problemem jest uwzględnienie tej literatury w badaniach z zakresu historii literatury.

Podniesienie prestiżu gwary nie dokona się przez zaprzeczenie jej charakteru, czyli twierdzenie, że gwara nie jest gwarą. Właściwym rozwiązaniem jest upowszechnianie wiedzy o języku polskim w całym jego bogactwie wynikającym ze zróżnicowania dialektalnego. W powszechnej świadomości pojęcie język polski jest utożsamiane z jego odmianą ogólną. Jeżeli w programie studiów polonistycznych nie ma dialektologii, to nauczyciel polonista nie dysponuje wiedzą pozwalającą mu zabierać głos w dyskusji, czy coś jest, czy nie jest dialektem. Należałoby postulować powrót 
do edukacji regionalnej w szkole, poprzedzony dobrym przygotowaniem dialektologicznym i etnograficznym nauczycieli. Wtedy będzie szansa, że identyfikacja ucznia tak z własną małą ojczyzną, jak i z tą wielką nie będzie przybierać charakteru pytania: jesteś Ślązakiem czy Polakiem?

Na koniec przytoczę podaną w Uzasadnieniu charakterystykę języka śląskiego:

Język śląski (rzondzyni, ślonsko godka, ślonsko mowa) definiuje się jako jeden z języków zachodniosłowiańskich wywodzący się wprost z języka prasłowiańskiego. Na kształtowanie się jego słownictwa miały wpływ zapożyczenia z języków: polskiego, czeskiego (a raczej morawskiego, funkcjonującego dawniej jako odrębny język), niemieckiego (częściej z germańskiego dialektu śląskiego, niż standardowego niemieckiego) oraz częściowo słowackiego. W języku tym przeważa źródłosłów słowiański. Znaczna część wyrażeń bliższa jest raczej językowi staropolskiemu, a konkretnie sąsiednim dialektom wielkopolskiemu i małopolskiemu oraz językom dolnołużyckiemu, górnołużyckiemu i morawskiemu, niż współczesnej standardowej polszczyźnie. Mowa śląska różni się od innych języków słownictwem, fonetyką oraz częściowo ortografią (Uzasadnienie: 9).

Twierdzenia zawarte w Uzasadnieniu są dobrą egzemplifikacją diagnozy, którą sformułował Władysław Lubaś (2012: 29):

Dialekty śląskie są genetycznie polskie, co nie ulega żadnej wątpliwości dla ludzi znających dobrze literaturę językoznawczą i badawcze metody lingwistyczne. Szarlatani "naukowi” jednak zawsze egzystują na marginesie każdej dyscypliny naukowej, a ich poglądy bywają pożywką dla przeróżnych koncepcji politycznych. Tak też się dzieje w przypadku polszczyzny śląskiej,

oraz pokazują, że wiedza o własnym języku nie jest w społeczeństwie polskim wystarczająca i pilnym zadaniem jest jej poszerzenie.

\section{Literatura}

Bystroń J., 1887, O mowie polskiej w dorzeczu Stonawki i Łucyny w księstwie Cieszyńskim, "Rozprawy i Sprawozdania z Posiedzeń Wydziału Filologicznego Akademii Umiejętności” XII, s. 1-110.

CinciaŁA A., 1882, Słownik dialektyczny Księstwa Cieszyńskiego, reprodukcja rękopisu, Wisła 1998.

CząstKa-Szymon B., 2009a, W sprawie rejestracji w Bibliotece Kongresu Stanów Zjednoczonych gwary śląkiej jako odrębnego języka, [w:] D. Kadłubiec (red.), Tradycja i współczesność. Folklor - Język - Kultura (materiały z międzynarodowej konferencji „Między tradycją a współczesnością", październik 2007), Bielsko-Biała, s. 305-321.

CzĄstKa-Szymon B., 2009b, O gwarze śląskiej w stulecie I wydania „Dialektów polskich Ślaska” Kazimierza Nitscha, „Konteksty Kultury” V, s. 125-133.

CząstKa-Szymon B., 2011, Wokót badań nad gwara śląską w perspektywie historycznej, [w:] K. Heska-Kwaśniewicz (red.), Śląskie Miscellanea, t. 24, Katowice, s. 40-48. 
Cząstka-Szymon B., Ludwig J., Synowiec H., 200o, Mały słownik gwary Górnego Śląska, Katowice.

CząstKa-Szymon B., Synowiec H., (w druku), Gdy dialekt staje się przedmiotem dyskursu politycznego - o sytuacji ślaskiej odmiany polszczyzny w mediach, Łódź.

Dejna K., 1973, Dialekty polskie, Wrocław.

EJP: S. Urbańczyk, M. Kucała (red.), Encyklopedia języka polskiego, Wrocław 1999.

Furdal A., 2000, Językoznawstwo otwarte, Wrocław.

Furdal A., 2002, Dialekt czy język - problem nie tylko lingwistyczny, [w:] J. Okoniowa, B. Dunaj (red.), Studia dialektologiczne II, Kraków, s. 37-41.

KLEMENsiewiCz Z., 1954, O różnych odmianach współczesnej polszczyzny, Warszawa [przedr. w: W kręgu języka literackiego i artystycznego, Warszawa 1961, s. 101-156].

KucaŁa M., 1960, O słownictwie ludzi wyzbywających się gwary, „Biuletyn Polskiego Towarzystwa Językoznawczego" XIX, s. 141-156.

LuBAś W., 2012, O polskiej polityce językowej, „Poradnik Językowy” z. 6, s. 11-33.

MAJEwicz A.F., 1989, Języki świata i ich klasyfikowanie, Warszawa.

MALINOWsKi L., 1873, Ueber die Oppelnsche mundart in Oberschlesien, Leipzig.

Nitsch K., 1909, Dialekty polskie Śląska (z mapą), „Materiały i Prace Komisji Językowej Akademii Umiejętności w Krakowie” IV, Kraków, s. 85-356.

Olesch R., 1958, Der Wortschatz der polnischen Mundart von Sankt Annaberg, Berlin.

SiUciak M., 2011, Historyczne podstawy świadomości narodowej Ślązaków, „Białostockie Archiwum Językowe" nr 11, Białystok, s. 223-235.

SKUDRZYK A., 2004, Współczesny komunikacyjny status gwar ludowych w opinii społecznej, [w:] H. Sędziak (red.), Polszczyzna Mazowsza i Podlasia, cz. 8: Antroponimia i toponimia Mazowsza i Podlasia, Łomża, s. 169-175.

SkUdRZYk A., Urban K., 2010, Małe ojczyzny. Świadomość językowo-kulturowa społeczności lokalnych, Katowice.

Skudrzy Kowa A., Tambor J., Urban K., Wolińska O., 2001, Gwara śląska - świadectwo kultury, narzędzie komunikacji, Katowice.

TАмвоR J., 2008, Mowa Górnoślązaków oraz ich świadomość językowa i etniczna, wyd. II, Katowice.

Ustawa z 6 stycznia 2005 r. o mniejszościach narodowych i etnicznych oraz o języku regionalnym, Dz. U. 2005, nr 17, poz. 141.

Uzasadnienie, [w:] Sejm Rzeczypospolitej Polskiej VII kadencja, Druk nr 567, Warszawa, 30 marca 2012 r. Projekt ustawy O zmianie ustawy o mniejszościach narodowych i etnicznych oraz o języku regionalnym, a także niektórych innych ustaw.

Wronicz J. (red.), 1995, Słownik gwarowy Śląska Cieszyńskiego, Wisła - Ustroń.

WroniCz J. (red.), 2009, Mały słownik gwar polskich, Kraków.

Wronicz J., 2010, Kultura szlachecka a kultura chłopska $w$ aspekcie jezzykowym, „Biuletyn

Polskiego Towarzystwa Językoznawczego" LXVI, s. 209-221.

Wyderka B., 2000-2012, Słownik gwar śląskich, t. I-XIII (A-J), Opole. 


\section{The speech of the Silesians: subdialect, dialect or a regional language (with reference to the attempted change of the legal status) \\ Summary}

The paper discusses a bill submitted to the Polish Parliament on recognition of the speech of the inhabitants of Upper Silesia as a regional language, and demonstrates that the said speech is a subdialect of the Silesian dialect of Polish. 